\title{
Frequency of Adjectives in Male and Female Speech in the Contemporary Television Drama Series "Homeland": A Corpus Study
}

\author{
Marian Żmigrodzki \\ Pedagogical University of Krakow, Poland \\ marian.zmigrodzki@gmail.com
}

\begin{abstract}
The paper addresses issues related to language and gender, and discusses research on the frequency of adjectives in language of male and female characters in a TV drama series "Homeland". The empirical part of the study uses as its theoretical background the classic works in the field (Lakoff 1975; Butler 1990; Meyerhoff 2006), which identify gender specific language features and define factors that determine male-female language differences. The research was conducted manually, with a limited support of electronic tools, on a personally created language corpus consisting of dialogue lines from the TV show. The results clearly show that the frequency of adjectives in female speech in the context of the TV series is higher than in male speech in the analyzed corpus.
\end{abstract}

Keywords: sociolinguistics, gender, male/female language, adjectives, corpus-based study

Streszczenie

Częstotliwość występowania przymiotników w mowie mężczyzn i kobiet we współczesnym serialu telewizyjnym "Homeland": badanie korpusowe

Niniejszy artykut porusza kwestie związane z zależnościami między językiem i płcia oraz przedstawia wyniki badania nad częstotliwościa występowania przymiotników w języku messkich i kobiecych postaci serialu telewizyjnego „Homeland”. Za podstawe teoretyczna części empirycznej badania postużyly klasyczne prace badawcze (Lakoff 1975; Butler 1990; Meyerhoff 2006), które wskazuja cechy szczególne dla języka w zależności od płci nadawcy oraz definiuja czynniki odpowiedzialne za różnice w języku kobiet i mężczyzn. Badanie zostało przeprowadzone ręcznie, z mała pomoca narzędzi elektronicznych, na osobiście stworzonym korpusie językowym zawierajacym listy dialogowe z serialu. Wyniki jasno pokazuja, że w 
badanym korpusie częstotliwość pojawiania się przymiotników w języku kobiet jest wyższa niż w języku mężczyzn.

Słowa kluczowe: socjolingwistyka, płeć, język mężczyzn/kobiet, przymiotniki, badanie na korpusie

\section{Introduction}

One of the topical issues in contemporary sociolinguistic studies is gender variation and numerous linguists are researching the differences between the language of women and men. Notable names in the field include R. Lakoff (1975a), J. Coates ([1993] 2004), P. Eckert (2003), S. McConnel Ginnet (2003), D. Tannen (1990), S. Salih (2002), and many more. This article tackles the issue of the usage of adjectives in the dialogue lines of male and female characters in the contemporary TV series Homeland. This type of text has been chosen due to its popularity among the general public and, consequently, its language shaping role in the society, as well as some other features discussed further in the article. The aim of this paper is to find out whether female speakers use more adjectives, and as a result more empty adjectives, defined by Lakoff as "adjectives that seem devoid of all but a vague positive emotive sense" (Lakoff 1975b). For the purpose of the research, we will analyze a complete list of dialogue lines of two seasons of Homeland and discuss the results.

To provide theoretical background for the research, The first part of the article addresses major issues in sociolinguistic studies on gender variation, a sub-branch of sociolinguistics, and discusses notions and terms relevant for the present research. This is followed by a description of the corpus and the methodology used. The empirical part presents the findings of the research, followed by a discussion and conclusions.

\section{Major issues in sociolinguistic studies on gender - literature overview}

This section explores how the study of the relationship between language and gender has grown throughout the recent decades to reach its current state. We discuss the change in the understanding of the term gender and the prevalent theoretical approaches and methods of studying the relation between gender and language. 


\subsection{Gender vs. sex}

The term gender, traditionally referring exclusively to grammatical categories in linguistic research, has been redefined along with the reformulation of the object of sociolinguistic research, which shifted from sex to gender (Meyerhoff 2006: 202). This is by no means an insignificant change. To show the significance of this shift of focus, both terms will be discussed in greater detail.

Following Eckert and McConnel-Ginet (2003: 10-11), "sex" is a category based purely on the human anatomy and reproductive properties, which every human is theoretically born with. This makes the classification based on sex simple, at least, in most cases, which is stressed by the authors.

Gender, while seemingly denoting the same concept, differs in many ways from the traditional understanding of the term sex. Gender is not a quality inherent to human beings, according to West and Zimmerman (1987: 125-127); gender is what we do rather than have, or what we perform, according to Judith Butler's theory of gender performativity (performance). The so-called "gender lore" is argued to be a social phenomenon rather than something objective, although many are tricked into believing otherwise, because of its omnipresence in a vast number of social situations.

Gender builds on biological sex, it exaggerates biological difference and, indeed, it carries biological difference into domains in which it is completely irrelevant. There is no biological reason, for example, why women should mince and men should swagger, or why women should have red toenails and men should not.

(Eckert, McConnel-Ginet 2003: 10)

Rather than a fixed personal characteristic, gender is a social feature which we build or acquire throughout interaction with the society. It is loyalty, or lack of it, to the social norms which define what people understand to be masculine or feminine (Meyerhoff 2006: 202).

Findings and theories from different scientific areas often intertwine and influence each other. The transition from sex to gender as a variable in sociolinguistic studies can be understood both as a necessary occurrence signifying progress in related sciences, and as a form of ascertaining that the actual object of research is not only the biological background of the speaker but also, or mainly, their social identity. Social identity is affected by the community, by ourselves, by interactions with other speakers, and gender is now understood to be a part of that identity. All of this may have an impact on one's language; consequently, in order to be thorough in their research, sociolinguists need to take all those aspects of speakers' identities 
into account. Relying solely on the physical features of the speaker is bound to provide incomplete or even completely bogus results (Meyerhoff 2006: 202).

\subsection{Gender performance and gender performativity theory}

A very important feature, which has an impact on language use and is therefore a factor that needs to be considered by sociolinguists, is gender performance. In her most well-known book, Gender Trouble: Feminism and the Subversion of Identity (1990), Judith Butler, an American philosopher and one of the most notable researchers of gender, outlines, among other things, her theory of gender performativity and disputes some of the more traditional ideas on gender.

Butler believes that all bodies are gendered; this is because they exist socially, and existence is always social in nature. This means that no natural body may pre-exist the cultural frames it is in. Following the above assumption, gender could not possibly be understood as a state, or what someone $i s$; it is what one does or performs, an act or a series of acts.

Gender is the repeated stylization of the body, a set of repeated acts within a highly rigid regulatory frame that congeal over time to produce the Subjects of Sex/Gender/Desire appearance of substance, of a natural sort of being.

(Butler 1990: 43-44)

The Gender performativity theory, however, should not be understood as to suggest that everyone can freely perform their gender of choice. As argued in the above quote, the acts need be performed within a "highly rigid regulatory frame". According to Butler (1990: 43-44), gender is performed by its own expression, which can at the same time be considered its result, as there is no gender identity that pre-dates performance.

Language and discourse, which are also performative, are vital parts in gender performance, because they are the very tools that construct and constitute gender (Salih 2002: 56). In the same way, it is not the speaker that performs the language or discourse, but rather it is the language or discourse that performs the identity of the speaker (Salih 2002: 56). Thus we can conclude that language and gender are inseparable from each other.

\subsection{Cornerstone of the studies in gender variation}

The person who is believed to be the first to investigate gender in connection to language and at the same time inspire research in this area is Robin Tolmach Lakoff, whose 1975 work Language and Woman's Place is considered the dawn of a new sociolinguistic subfield, that 
focuses on the interdependence of language and gender. Lakoff's work has been re-released as an expanded edition with extensive commentaries from other linguists.

Lakoff argues that the speech of women differs in various aspects from the speech of men, and that there are certain traits in women's utterances that are mainly conditioned by the historical oppression of women (1975: 51-64). The author lists nine features which, according to Lakoff (1975: 53-55), are characteristic of women's language. Lakoff argues that the preferential nature of these features is due to the fact that underlyingly they are related to what the author calls "power in the real world", which makes it possible for both men and women to use them. At the same time, however, Lakoff asserts that these features are more intrinsic to the speech of women, who have generally been in a position with less power in the real world.

One of the features Lakoff lists is the extensive range of vocabulary related to activities traditionally considered to be woman's work, e.g.: magenta, dart, shirr (sewing). The author asserts that if men use those words, it is never in a serious manner. One other feature is the presence of the so-called empty adjectives, which are typically recognized as cordial, sophisticated and polite, e.g.: charming, divine, cute. This feature is particularly relevant to the focus of this paper, as the main research aim is to test whether the speech of women in the TV show includes more of these adjectives. This will be done by measuring the total number of the adjectives within the language sample, and comparing the frequency of the usage between men and women. Significantly higher frequency of adjectives in one of the samples would mean that more of the empty adjectives will inherently occur in said sample as well. Another feature of women's language is the question intonation in utterances one normally considers declaratives. For instance: tag questions: It's so hot, isn't it? and rising intonation in statements, e.g. What's your name, dear? are attributed to women's language use. Another feature is the usage of the so-called hedges, i.e. words that are used to convey uncertainty or lack of accuracy of a statement, e.g. you know, sorta, well, kinda. In the author's opinion, the usage of these words is understandable when the meaning of uncertainty needs to be conveyed, but women tend to overuse them in order to mitigate the potential unkindness or unfriendliness of a statement. Women's language is also characterized by the overt usage of the intensive -so-, used with the intention to hide one's strong feelings, e.g.: I like him so much is much less clear and conveys a lower intensity of feelings than I like him very much. One other feature enumerated by Lakoff is the hypercorrectness and preference for the use of standard forms of language, which stems from the traditional view that women are supposed to be the preservers of literacy and of proper language. The use of superpolite forms is also attributed to women who are raised to be polite and cultured, and never to resort to crude language. Another feature mentioned by the author 
as characteristic of women's language is the inability to tell jokes due to mixing the order and ruining the punchline; Lakoff states that it is universally believed in the American society that women do not have a sense of humour. Finally, women tend to speak in italics, or, in other words, strengthen the conveyed utterance through various intonation operations, which is a sign of the lack of confidence and feeling that you have to use double force in order to communicate your message, as if the words themselves were not enough. According to Lakoff, there are apparently many more features inherent to women's speech, which are difficult to describe due to their elusive and intangible nature. In Language and Woman's Place (1975), Lakoff first outlined her theory of politeness and mentioned the newly coined three maxims of politeness.

Lakoff's book has received major criticism in the scientific world. It has been asserted that for claims so fundamental, the author did not produce enough empirical evidence, and it has been claimed the book could not be considered as properly researched, relying mainly on the authors beliefs. Despite these criticisms, it is widely agreed that Language and Woman's Place (1975a) worked as an impetus. According to Robin Lakoff's own words (1975a: 43), she did not consider her book to be the final solution to the issue, but rather "a goad to further research". Today we can say that R. Lakoff has achieved her goal. Her book was the catalyst which has prompted researchers to start investigating the issue of gender differences and similarities in language (Coates [1993] 2004: 5).

\subsection{Main approaches to research on gender in sociolinguistics}

Thanks to gender-related sociolinguistic research, there are hopes that reaching the point at which some general claims based on the actual language performance of speakers might be reached. Since the publication of Robin Lakoff's book, the approaches to studying gender in relation to language have varied. Coates ([1993] 2004: 6-7) enumerates four major approaches, which are commonly referred to as: the deficit approach, the dominance approach, the difference approach and the dynamic (also known as the social constructionist) approach.

Although the approaches surfaced in a chronological order, however, the appearance of each new approach did not mean that the former became obsolete. Even though, according to Coates ([1993] 2004: 6-7), currently the dynamic approach seems to be the prevalent one, they often co-existed and competed with one another.

Typical of the initial research in the field is the deficit approach, of which Robin Lakoff's book is the signature example. In the deficit approach, the features attributed to women's language were shown as inferior to the language of men, or simply lacking some characteristics 
and thus considered deficient. This approach was criticized for its claim that women's language is inherently flawed, which was a value judgement rather than an assessment of variation between female and male language.

In the dominance approach, the core focus of research is the women's subordinate role in the society. All the differences in language are therefore subscribed to women being the oppressed part of the society. One of the main aims of this approach is to describe how the process of women's subordination is perpetuated through linguistic practice, that involves both men and women, and is often unintentional (Coates [1993] 2004: 6-7). An emblematic example of a language phenomenon that reinforces inequality is, according to Coulmas ([2005] 2013: 45-47), one of the naming conventions, which makes the wife and the child adopt the husband's name. Those following the dominance approach would have considered it a device enacting male domination.

The difference approach tackles the issue from yet another perspective. Women and men are seen as members of two groups, or subcultures, neither of which should be perceived as inferior to the other. This approach has been popularized by Deborah Tannen in her You Just Don't Understand: Women and Men in Conversation (1990). At the same time Tannen and other proponents of the difference approach distance themselves explicitly from the deficit and dominance approaches.

The difference approach has received criticism because it often led to overgeneralisations, which made linguists adopt positive bias for women's language and at the same time, overtly criticize the language of men. The former was often perceived as more cooperative, while the latter as more aggressive and full of ambition (Wodak, Benke 1998: 88-91).

The most recent and currently most widely applied is the dynamic or social constructionist approach. The focus, as the name suggests, are the dynamics of discourse and interaction between speakers. This approach is based on modern gender theories from various fields of science, which assume that gender is a socially constructed feature that subjects perform, rather than simply a static trait or a fixed social category which can be traced back directly to the physical features of the human body. The development of the performativity theory by Judith Butler had a significant impact on the perception of the role of language. As gender became something one does or performs instead of what one is, language turned into another tool the speakers employ to perform their gender.

It is worth noting that the lack of rigid boundaries between the approaches: and their overlapping, - except for the quite forgotten deficit approach, - influence the gender-related sociolinguistic research nowadays, with the dynamic approach being the prevalent one. 


\section{The study}

This section reports on a research study on the frequency of adjectives in the speech of male and female characters in the contemporary TV drama series Homeland. Findings and results will be presented in the form of tables, separately for the first and second season, as well as for the whole material.

\subsection{Language data}

Last decade has witnessed, a paradigm shift in the approach to TV series as a cultural medium. What has traditionally been perceived as of low quality and even as a plebeian form of motion picture storytelling, has undoubtedly been taken to new heights. Thanks to industry giants such as HBO, Showtime, AMC and other companies, that have started investing in major serialized TV productions, the status of contemporary TV drama series has been elevated and is no longer considered a shameful leisure.

Recent years have brought an increasing linguistic interest in contemporary TV drama shows, which may be attributed to their two features. Due to their popularity, they are an emanation of, at least some, speech habits of the target audience, and they may influence the audience's speech, both consciously and subconsciously. It also has to be noted that thanks to the Internet these shows are watched by millions of viewers worldwide, which makes them relevant material for studying the usage and performance of language in the present day.

The corpus used for this research is a dialogue list from the first two seasons of Homeland, an American production by Showtime Networks which tells a story of a female CIA officer, Carrie Mathison, afflicted by a mental disorder. The protagonist receives a piece of intel, saying that one of the American prisoners of war has been turned. Soon after, a marine sergeant Nicholas Brody is rescued from a terrorist compound in Iraq after 8 years of captivity. Carrie sets out to prove that Brody is not the hero everyone believes him to be.

Homeland can be characterized by a range of features which are either essential or largely helpful for the present research. They include: the presence of a female protagonist, no visible gender dominance among the characters, and the intelligence agency/military/political setting, which makes the show heavily nested in the American reality. The researcher's personal affection has also played a role in the final choice of the material, though it has not been prioritized over objective merits. 


\subsection{Assumptions, aims and research question}

Section 2 discusses stereotypes and assumptions about how the language of male and female speakers differs. The purpose of this research is to test whether within this drama series, women use more flowery and ornate language than men, which manifests in a more extensive usage of empty adjectives, as defined by Lakoff. This claim can be traced back to the very beginnings of gender-related studies, namely to one of the features identified by Lakoff as typical of women's language. Our present research has been conducted within the framework of the difference approach, as the language samples are compared and contrasted against each other without taking into account the power dynamics between genders and without deeper analysis of the societal background. The research is based on a popular TV series which can potentially influence the speakers and their language use in real life. Therefore even though definitive conclusions cannot be drawn about the English language as a whole based on this data, the results obtained for this particular type of discourse can be seen as relevant for further research. One of the features of women's language listed by Lakoff (1975: 53-55) is the supposed overt usage of empty adjectives. The usage of adjectives can therefore be treated as a genderpreferential feature, as discussed in Section 2 of the paper, rather than an exclusive feature. This is because this usage of adjectives can be found in the dialogue lines of both female and male speakers, while one of the genders is believed to have more inclination to use them.

The following research on adjective frequency in female and male speakers' utterances aims to check whether women indeed use more adjectives. This research is chiefly quantitative and thus it is assumed that an overall volume of adjectives correlates to the overall volume of empty adjectives. We assume that the regular average usage of adjectives would be elevated in the case of women really using more empty adjectives in speech. This is a simplification necessitated by the software tools used to conduct the research. The final goal is to arrive at an average number of adjectives per dialogue line for both genders and for all the adjectives in total, so the values could then be compared and a conclusion arrived at.

The action of the show takes place in an environment that could arguably be described as typically male due to the military theme. Therefore all the characters, regardless of their gender, are expected to exhibit more language features that are typically understood as 'manly'. It could then be assumed that female speakers should be less stereotypical and the frequency of adjectives in their dialogue lines should not differ from that of male speakers. At the same time, if it turned out that the frequency of adjectives does differ between the two genders, it could be 
further understood that outside of the military environment the difference would be even greater.

\subsection{Research methodology and tools}

The language data used for this research were compiled mostly manually. The dialogue lists in the format of .txt files were compiled in one folder. The analysis of the dialogue lines was accompanied by watching the episodes in real time. To ensure that all dialogue lines are correctly marked as produced either by female or male speakers and that the excerpted adjectives are correctly identified, for example in those cases in which lexical items function as different parts of speech.

A number of adjustments had to be made in order to turn the dialogue list into a workable corpus; most of those were deletions of certain parts of the text. The series uses a system of short introductions at the beginning of every new episode which remind the viewers what happened in one or more of the previous ones. Those sections have been cut out, as they are not part of the dialogues of the actual story line. The subtitles also contain non-linguistic utterances, lines for the hearing impaired, songs, and occasional lines in non-English languages; all of those were removed for the purpose of this study. The following are examples of such removed lines:

(93)

00:03:48,463 --> 00:03:49,530

(grunting)

(435)

00:23:37,367 --> 00:23:39,568

(door opens)

In this research, a dialogue line refers to a piece of text that is displayed on the screen at one time. This means that longer utterances are inevitably split into more than one dialogue line. This practice has no negative effects on the findings, as it is used in the case of all characters and genders in the show. The example below is thus counted as three dialogue lines:

00:06:30,414 --> 00:06:32,649

$\mathrm{He}$ is just riding out his term,

00:06:32,650 --> 00:06:34,551

and if that means

leaving a nuclear Iran 
(121)

00:06:34,552 --> 00:06:38,788

for the next administration

to deal with, what's he care?

Conversely, very short utterances and situations in which characters are having a quick exchange presents a different difficulty, namely, a dialogue line shared by two utterances. For the purpose of this research, such dialogue lines are counted as two lines. In other words, the total count of the dialogue lines goes up by 1 for each such case. The reason for the number of dialogue lines to be altered in such cases is the presence of not only two separate sentences, but two separate speakers, often of different genders. The following example illustrates a short exchange of civilities between a man and a woman; it is therefore counted as two dialogue lines, instead of just one:

164

00:08:41,371 --> 00:08:42,371

- Bye.

- Bye-Bye.

All the dialogue lines and adjectives used by both genders were noted down and counted manually to ensure precision, some of which would have been lost if automatic tools had been employed. At an early stage of the research, we also considered investigating the adjective to word form ratio. This idea was later abandoned due to the understanding of the term 'dialogue line', employed in this study. As the term 'dialogue line' is used here to refer to the text visible on the screen at one time, we refrained from examining the adjective to word form ratio. This is because after calculating the values for word per line averages, we would have ended up with the same ratios. Every dialogue line can be represented as a specific amount of words on average, therefore calculating adjective to word ratio would be nothing more than multiplying the number of lines by $\mathrm{X}$ in all cases. As a result, the same conclusions would have been reached, but with different numerical values. Such undertaking would constitute a lot of additional work with no added benefit.

The most frequently used adjectives, an additional part of the research, were assembled automatically with the trial version of 'AKS Word Count', which offers a set of slightly more 
advanced tools than normally available in MS Word. Complete lists of adjectives for each gender were scanned and instances of the same adjectives were counted to produce the list.

\subsection{Findings and discussion}

Tables 1-4 present the findings of the research. Tables 1 and 2 present seasons 1 and 2 of the show respectively, table 3 presents the overall statistics, and table 4 presents the additional insight into the most frequent adjectives used in the whole language sample.

Table 1. The usage of adjectives in Season 1 of Homeland. Overall statistics. Source: author.

\begin{tabular}{|c|c|c|c|c|}
\hline \multicolumn{5}{|c|}{ Season 1 Overall Statistics } \\
\hline General: & \multicolumn{4}{|l|}{ Number } \\
\hline Adjectives & \multicolumn{4}{|l|}{1564} \\
\hline Dialogue lines & \multicolumn{4}{|l|}{9350} \\
\hline Dialogue lines (m) & \multicolumn{4}{|l|}{5397} \\
\hline Dialogue lines (f) & \multicolumn{4}{|l|}{3953} \\
\hline Findings: & Number & $\begin{array}{l}\% \text { of all } \\
\text { adjectives }\end{array}$ & $\begin{array}{l}\text { Tokens/Dialogue } \\
\text { Lines Ratio }\end{array}$ & $\begin{array}{l}1 \quad \text { adjective } \\
\text { every ... lines }\end{array}$ \\
\hline Adjectives (total) & 1564 & $100 \%$ & $1564 / 9350$ & 5.98 \\
\hline Adjectives (m) & 832 & $53.20 \%$ & $832 / 5397$ & 6.49 \\
\hline Adjectives (f) & 732 & $46.80 \%$ & $732 / 3953$ & 5.40 \\
\hline
\end{tabular}

Table 2. The usage of adjectives in Season 2 of Homeland. Overall statistics. Source: author.

\section{Season 2 Overall Statistics}

General:
Adjectives
Dialogue lines
Dialogue lines (m)
Dialogue lines (f)
Findings:
Adjectives (total)
Adjectives (m)
Adjectives (f)

\begin{tabular}{|c|c|c|c|}
\hline \multicolumn{4}{|l|}{ Number } \\
\hline \multicolumn{4}{|l|}{1233} \\
\hline \multicolumn{4}{|l|}{8689} \\
\hline \multicolumn{4}{|l|}{5210} \\
\hline \multicolumn{4}{|l|}{3479} \\
\hline Number & $\begin{array}{l}\% \text { of all } \\
\text { adjectives }\end{array}$ & $\begin{array}{l}\text { Tokens/Dialogue } \\
\text { Lines Ratio }\end{array}$ & $\begin{array}{l}1 \quad \text { adjective } \\
\text { every ... lines }\end{array}$ \\
\hline 1233 & $100 \%$ & $1233 / 8689$ & 7.05 \\
\hline 667 & $54.1 \%$ & $667 / 5210$ & 7.81 \\
\hline 566 & $45.9 \%$ & $566 / 3479$ & 6.15 \\
\hline
\end{tabular}


Table 3. The usage of adjectives in the first two seasons of Homeland. Overall statistics. Source: author.

Overall Statistics

\begin{tabular}{|c|c|c|c|c|}
\hline General: & \multicolumn{4}{|l|}{ Number } \\
\hline Adjectives & \multicolumn{4}{|l|}{2797} \\
\hline Dialogue lines & \multicolumn{4}{|l|}{18039} \\
\hline Dialogue lines (m) & \multicolumn{4}{|l|}{10607} \\
\hline Dialogue lines (f) & \multicolumn{4}{|l|}{7432} \\
\hline Findings: & Number & $\begin{array}{l}\% \text { of all } \\
\text { adjectives }\end{array}$ & $\begin{array}{l}\text { Tokens/Dialogue } \\
\text { Lines Ratio }\end{array}$ & $\begin{array}{l}1 \quad \text { adjective } \\
\text { every ... lines }\end{array}$ \\
\hline Adjectives (total) & 2797 & $100 \%$ & $2797 / 18039$ & 6.45 \\
\hline Adjectives (m) & 1499 & $53.59 \%$ & $1499 / 10607$ & 7.08 \\
\hline Adjectives (f) & 1298 & $46.41 \%$ & $1298 / 7432$ & 5.73 \\
\hline
\end{tabular}

Table 4. Most frequent adjectives. Source: author.

\section{Most frequent adjectives}

\begin{tabular}{|c|c|c|c|c|c|c|c|}
\hline \multirow{2}{*}{\multicolumn{4}{|c|}{$\begin{array}{l}\text { Male } \\
\text { Total adj.: } 1499\end{array}$}} & \multicolumn{4}{|c|}{ Female } \\
\hline & 1499 & & & Tota & 1298 & & \\
\hline \multicolumn{4}{|c|}{ Total unique adj.: 554} & \multicolumn{4}{|c|}{ Total unique adj.: 467} \\
\hline No. & Adjective & Count & $\begin{array}{l}\% \text { of all } \\
\text { adj. used } \\
\text { by male }\end{array}$ & No. & Adjective & Count & $\begin{array}{l}\% \text { of all } \\
\text { adj. used } \\
\text { by female }\end{array}$ \\
\hline 1 & good & 99 & $6.60 \%$ & 1 & good & 66 & $5.08 \%$ \\
\hline 2 & right & 36 & $2.40 \%$ & 2 & right & 35 & $2.70 \%$ \\
\hline 3 & better & 29 & $1.93 \%$ & 3 & fine & 27 & $2.08 \%$ \\
\hline 4 & sure & 24 & $1.60 \%$ & 4 & sorry & 26 & $2.00 \%$ \\
\hline 5 & bad & 24 & $1.60 \%$ & 5 & wrong & 23 & $1.77 \%$ \\
\hline 6 & okay & 22 & $1.47 \%$ & 6 & okay & 22 & $1.69 \%$ \\
\hline 7 & fine & 22 & $1.47 \%$ & 7 & late & 22 & $1.69 \%$ \\
\hline 8 & long & 20 & $1.33 \%$ & 8 & sure & 20 & $1.54 \%$ \\
\hline 9 & safe & 19 & $1.27 \%$ & 9 & crazy & 19 & $1.46 \%$ \\
\hline 10 & crazy & 18 & $1.20 \%$ & 10 & last & 19 & $1.46 \%$ \\
\hline 11 & ready & 18 & $1.20 \%$ & 11 & ready & 17 & $1.31 \%$ \\
\hline 12 & sorry & 18 & $1.20 \%$ & 12 & important & 17 & $1.31 \%$ \\
\hline 13 & great & 18 & $1.20 \%$ & 13 & alive & 15 & $1.16 \%$ \\
\hline 14 & dead & 17 & $1.13 \%$ & 14 & better & 15 & $1.16 \%$ \\
\hline
\end{tabular}

A total of 18,039 dialogue lines were analyzed, of which 10,607 were uttered by male and 7,432 by female characters. A total of 2,797 adjectives were found. Male speakers used 1,499 adjectives, while females used 1,298. The number of male dialogue lines exceeds the number of female lines by 3,175 , and that is why the overall number of adjectives used by men is higher 
than the overall number of adjectives used by women by 201, even though they are less frequently used in the speech of the male characters in the show. The final overall figure of 1 adjective every...lines was 7.08 for male and 5.74 for female, which means that on average women use adjectives more often than men. While the disparity may not appear as very significant at first, it is consistent and the same tendency has surfaced in most of the single episode statistics. Another aspect which has to be taken into account was the environment the show is set in, which would suggest that women in this drama series would speak in a way that is stereotypically considered 'manly'. As it turned out, even in this typically male setting, female speakers still clearly expose more frequent usage of adjectives.

One piece of information which was not expected to be found out in this research is the disparity between the number of male vs. female dialogue lines, which, in consequence, affects the overall number of adjectives. Despite the show's main character being female and a reasonable number of female characters featured, men still talk more than women in the series.

The highest adjective frequency for female speakers occurred in Episode 11, and amounted to 1 adjective every 3.41 lines, while the lowest frequency was noted in episode two and amounted to 1 adjective every 9.09 lines. There were only three cases of this ratio going above 8 for female speakers across all of the episodes.

When it comes to the highest frequency of adjective usage for male speakers, it occurred in episode 10. The frequency was 1 adjective every 4.03 lines. This also seems to be plotinduced, as the episode consists mainly of a backstory of a certain male character and features many drastic moments which boost the usage of adjectives. The lowest frequency for male speakers was noted in Episode 23 and amounted to 1 adjective every 10.76 lines. In total, there were nine cases of this ratio going above 1 adjective every 10 lines among all of the episodes.

When it comes to the total number of unique adjectives used by either gender, male speakers are seemingly in the lead, but this is largely due to the greater number of male dialogue lines, and a higher overall number of adjectives. If the number of unique adjectives is contrasted with the total number of adjectives used by a given gender, the conclusion is that neither male nor female speakers have significantly broader vocabulary at their disposal. There does not seem to be a large disparity among the most frequently used adjectives either. As shown in Table 4, most of the frequently used adjectives overlap between men and women. Out of fourteen most frequently used adjectives, nine are shared between the two lists. 


\section{Conclusion}

The research has provided very clear and consistent results. Female characters, despite being intelligence officers or at least being immersed in the military environment, use adjectives more often than male speakers, which confirms one of Lakoff's (1975a: 53-55) major claims about women's language. According to Lakoff (1975a: 53-55), using more empty adjectives is caused by women's need to be more polite than men, and less straightforward in their communication. This language feature was one of the core parts of the now outdated deficit approach which considered the language of women as inferior to language of men. The most surprising result is that the series was specifically chosen as one that might potentially go against the stereotypes about women's language and it ended up failing to do so. As it turned out, this shared environment did not affect the frequency of adjectives used by female speakers, which remained higher than that of male speakers.

Statistical significance was not calculated for the data, thus limiting the conclusions to the examined language sample. Further research on a broader scale, examining the language of different social groups and environments, is needed in order to confirm the presence of this phenomenon in the language of American native speakers in general.

\section{References}

Butler, Judith (1990) Gender Trouble: Feminism and the Subversion of Identity. New York: Routledge.

Carter, Ronald A., Michael J. McCarthy (2006) The Cambridge Grammar of English: Spoken and Written English Grammar and Usage. Cambridge: Cambridge University Press.

Coates, Jennifer ([1993] 2004) Women, Men and Language. New York: Routledge.

Coulmas, Florian ( [2005] 2013). Sociolinguistics: The Study of Speakers' Choices. Cambridge: Cambridge University Press.

Eckert, Penelope, Sally McConnel Ginnet (2003) Language and Gender. Cambridge: Cambridge University Press.

Ito, Rika, Sali Tagliamonte (2003) 'Well Weird, Right Dodgy, Very Strange, Really Cool: Layering and Recycling in English Intensifiers." Language in Society 32; 257-279.

Lakoff, Robin (1975a) Language and Woman's Place. New York: Harper Row Publishers. Lakoff, Robin (1975b) Women's Language. [In:] Women's Language and Style; 139-158. 
Lakoff, George (1973) "Hedges: A Study in Meaning Criteria and the Logic of Fuzzy Concepts." Journal of Philosophical Logic 2 (4); 458-508. DOI: https://doi.org/10.1007/BF00262952.

Meyerhoff, Miriam (2006) Introducing Sociolinguistics. New York: Routledge.

Murphy, Brona (1996) Corpus and Sociolinguistics Investigating Age and Gender in Female Talk. Amsterdam, Philadelphia: John Benjamins Publishing Company.

Prince, Ellen, Joel Frader, Charles Bosk (1982) “On Hedging in Physician-Physician Discourse." [In:] Robert J. di Pietro (ed.) Linguistics and the Professions. Hillsdale NJ: Ablex; 37-43.

Quirk, Randolph, Sidney Greenbaum, Geoffrey Leech, Jan Svartvik (1985) A Comprehensive Grammar of the English Language. London \& New York: Longman.

Salih, Sara (2002) “On Judith Butler and Performativity.” [In:] K. Lovaas, M. M. Jenkins (eds.) Sexualities and Communication in Everyday Life: A Reader.

Stoffel, Cornelis (1901) Intensives and Down-toners. Heidelberg: Carl Winter.

Tannen, Deborah (1990) You Just Don't Understand: Women and Men in Conversation. William Morrow Paperbacks.

Wodak, Ruth, Gertraud Benke (1998) „Gender as a Sociolinguistic Variable: New Perspectives on Variation Studies". [In:] Florian Coulmas (ed.) The Handbook of Sociolinguistics. Oxford: Blackwell Publishing; 88-104.

West, Candace, Don Zimmerman (1987) “Doing Gender.” Gender and Society 1; 125-151. 